Open Access

\title{
Green governance and green clusters: regional \& national policies for the climate change challenge of Central \& Eastern Europe
}

Philip Cooke

Correspondence:

CookePN@cardiff.ac.uk

Center of Innovation, Bergen

University College, Bergen, Norway

\begin{abstract}
This paper focuses on the climate change challenge faced by Central \& Eastern European countries both those inside the European Union and those outside it. They have enormous energy intensity and associated greenhouse gas (GHG) emissions, mainly from energy production, which is oil, and worse, coal-fired power stations. As a group of blocs, CEE is a significant actor on the global climate change canvas. Their actions can make a difference. But there are numerous regulatory constraints that make this currently difficult. With the onset of a new global regime consequent on the renegotiation of acceptable levels of GHG emissions at Bali in 2007, to be ratified in Copenhagen in 2009, all countries with levels such a those in CEE will have to reduce emissions significantly as will countries throughout the world, especially the 'big burners' like USA and China. With some data and textured case illustrations the article points the way to mitigation of emissions by learning from Denmark, the world leader as a 'green economy' and Wales, part of the UK which has a long established heavy industry tradition comparable to many CEE countries and where positive change is underway from unlikely sources.
\end{abstract}

JEL: A14; O33; R11; R58

Keywords: Green governance; Green innovation; Green clusters; Renewable energy; Wind turbines; Solar thermal energy; Biofuels

\section{Background}

This contribution involves reflecting on the variety of governance and policy responses by cities to climate change. Climate change refers to the historically measurable increasing rate of atmospheric 'greenhouse gases', particularly carbon dioxide $\left(\mathrm{CO}^{2}\right)$. While there is debate about the causes of climate change, there is consensus that human activity has made a contribution to it since the onset of industrialisation and especially in the very recent past (Bastianoni et al. 2004). The future contribution of cities to mitigating climate change will concentrate upon the four key content areas that research has shown to be main contributors to increased $\mathrm{CO}^{2}$ and other greenhouse gases, all of which are connected to urban governance. These are food consumption, passenger transport, energy use and municipal waste. Following one of the numerous Stockholm Environment Institute's reports (Stockholm Environment Institute 2005) consumption of food accounts for some $24 \%$ of emissions making up a 
given territory's 'ecological footprint', passenger transport and energy use each contribute $18 \%$ while municipal waste accounts for $26 \%$. The remainder is accounted for by such activities as housing, government and services.

How should cities begin the process of moderating these emissions? They must first know their emissions profile and identify which are badly out of line with acceptable norms. Ecological footprint assessments constitute a credible entry point to the formation by a city (or county) of a strategy to take actions that reduce emissions. In the case of food consumption, it can take direct action to utilise, and even grow, less energy intensive organic food and/or use localised food chains to supply canteens for which it may have sole responsibility (e.g. schools, care homes, administration) as well as animating similar approaches in other public (e.g. hospitals, higher education), private and domestic food consumption environments such as any local food and/or health alliance (Alliance 2004). Regarding passenger transport, city governance may involve using renewable fuels in public bus and delivery fleets, encouraging greater public transport use, using planning policy to limit sprawl and traffic while providing cycleways, green space and downtown housing accommodation. With respect to other energy utilisation, cities can change their purchased energy consumption to renewable sources and install biomass or other clean energy technologies where they generate their own. This connects to the area of municipal waste, which through adoption of waste recycling, can supply biomass for energy production. For energy waste itself, energy-saving initiatives can be taken directly on city-owned buildings, street-lighting, traffic lights, other heating and lighting and nurseries, also indirectly by encouraging energy saving among citizens.

Research must explore all these and more aspects of city governance in the context of climate change, seeking to explain why some are pioneers, early adopters and committed implementers of actions responsive to the widely-perceived need for reductions in greenhouse gases, and why some are latecomers or uncommitted to taking such actions directly or indirectly.

The relevance of supranational, national and sub-national regulation, such as the Rio, Kyoto framing and Montreal (Kunstler 2005) binding climate change protocols; the EU European Climate Change Programme and EU Emissions Trading Scheme; national energy and climate change strategies; and relevant sub-national initiatives should be taken into account. In the third section, this contribution will proceed with the elaboration of a matrix of the spectrum of city take-up qualities from city leadership to apparent city apathy on the $x$-axis, against governance relations on the $y$-axis (on mayors good and bad, see (Lever 2001)). The latter spectrum will include categories capturing political composition (hypothesising, for example, that Green political representation or sympathies exert leadership and commitment), officer influence (e.g. including multi-level governance and strategy expertise), transnational sustainability networks (e.g. EU Sustainable Cities Network), associative governance (active climate-change lobbying by civic societies), knowledgeable governance (e.g. interfaces between city policy and specialist research or advocacy institutions), business context (local presence of, for example, 'cleantech' business, influential and demanding 'green' corporate citizens ((Freeman et al. 1996; Gibbs et al. 2002), who associate local sustainability policy with 'good governance'). The discovery of combinations or multiple absences of such relational factors in association with leadership and measurable commitment will also be taken into account and efforts made to find other explanations for both non-relational commitment and relational apathy in 
relating performance to governance category. As Gibbs et al., (Gibbs et al. 2002) note, contrariwise, a 'pro-growth' city regime may exercise 'good governance' that is not good for limiting greenhouse emissions. Thus there is an ethical hierarchy to be teased out conceptually and empirically. In this, there is an implication that the exigencies of moderating climate change are superior to those of promoting 'good business climates' (Stern 2007).

Naturally, research needs to be informed by and conducted against benchmarks or at least templates of known good practice exemplars. Here, these will be drawn from two Scandinavian cities of different sizes, both with strong international reputations for demonstrable commitment and achieved outcomes in some or all of the content areas noted above. The cities are Copenhagen, Denmark and Malmö, Sweden. Briefly, both tackled the first content area - agro-food - by transforming food procurement from conventional to organic, Copenhagen including schools, hospitals, day care and longterm care homes, Malmö mainly schools. Together, these city strategies on organic canteen food alone contributed to a $2.25 \%$ reduction in $\mathrm{CO}^{2}$ emissions from their institutional food chains. In the second content area, Malmö's municipal car fleet has, in 2007, 150 of a planned 250 'cleantech' vehicles, passenger transport $\mathrm{CO}^{2}$ emissions have reduced by 10-15 \% in Copenhagen 1996-2006 following establishment of urban environmental zones and clean technology measures. With respect to content area four, in Copenhagen up to $80 \%$ of city household waste is used in Energy from Waste (EfW) power plants while over $70 \%$ of all waste is recycled. Regarding energy, the third content area, more than $25 \%$ of electricity generation in Copenhagen is from renewables, notably wind ( $4 \%$ ) and solar power (3\%) in addition to waste (26\%). Malmö has approved building of a biogas from waste biofuels plant. Copenhagen had, from 1990 to 2005 reduced overall $\mathrm{CO}^{2}$ emissions by $23 \%$. It is planned to reduce by $35 \% 1990$ 2010. These achievements led to Copenhagen being elected Environmental Capital of Europe and International Solar City. In its latest Agenda 21 Plan Copenhagen's own energy consumption is planned to be reduced by 5 \% 2002-2007 Copenhagen Environmental Protection (Agency 2006; City of Malmö Environment Department 2006).

The research objectives of this chapter and its content are, accordingly, as follows. First, it outlines ways to determine theoretically reasons for variety in the extent of commitment by cities to policy agendas prioritising measures designed to minimise emissions believed to be significant contributors to climate change. Second, it suggests ways to develop better urban governance theory through contributing new comparative conceptual and some limited empirical material on interpreting substantive policy rationales that cities may pursue, such as pro-growth versus pro-green, and possible resolutions of apparent conflicts. Third, it addresses ways to evolve a typological framework for categorising cities according to 'sustainability performance' on the $\mathrm{x}$-axis and their 'governance mode' on the y-axis (Fig. 1). Fourth it indicates how to test the typology in Fig. 1 utilising the four key performance variables identified for all cities as controlling emissions from: food consumption; passenger transport; energy use; and municipal waste, against three governance modes: inclusive governance/responsive government; responsive governance/proactive government; exclusive government/reactive governance. Finally, it hints at ways to derive a governance/government taxonomy of cities according to the extent they interact measurably with any of six governance contexts: political composition, officer influence, transnational sustainability networks, associative governance, knowledgeable governance, and 'cleantech' business interaction. 


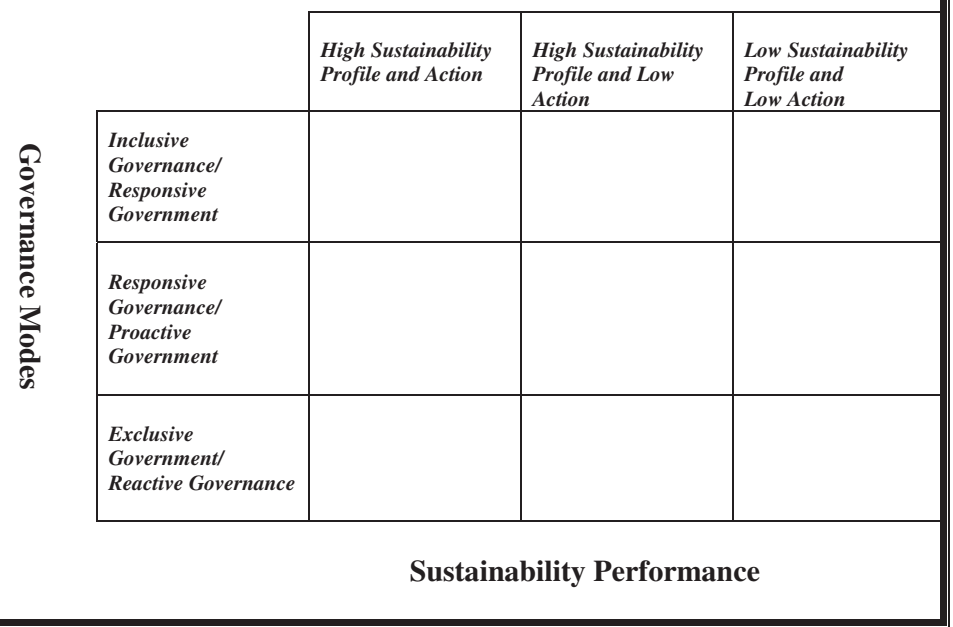

Fig. 1 Governance-performance typology framework for city sustainability

\section{Theoretical issues and analysis}

Given the rising popular concern and mounting evidence of climate change due at least in some measure to the increase in greenhouse gases like carbon dioxide $\left(\mathrm{CO}^{2}\right)$, nitrous oxide, and methane (Stern 2007), it is perhaps surprising that urban governance research has produced few studies of the policy achievements of cities for controlling emissions that contribute to global warming. The exemplar discussed in the introduction, Copenhagen, has no such research reported and the reported data had to be extensively data-mined, also for Malmö. One conference paper only, written by engineers, could be found dealing with the larger city's Dogma institutional food and environment project, for example (Jensen \& Tollin 2004). The key point regarding governments, and cities particularly in this context, is that they are the main variant to markets as stimulators of change. While markets clearly exist for certain clean technologies, notably wind energy; in Denmark, a leading producer of wind turbines, the technology was subsidised from the 1970s until 2000, much as the US government currently heavily subsidises biofuels and clean technology. Clearly cities are not immune from markets, but they can exert a market-shaping pressure through regulation and purchasing.

In researching this contribution, we found a mid-size British city like Bristol (population 500,000) having installed low-energy street lighting, built a biomass heating system for its horticultural recquirements, and purchasing renewable energy ('green electricity') for a dozen major council-owned facilities, including a concert hall. In addition it promotes green practices among its citizens through a variety of initiatives. Finally, Bristol has reached the appropriate standard to be included as a 'Transition Town' in an initiative promoted by the UK's Soil Association. The Soil Association is the private regulatory body responsible for officially designating farms and food as 'organic'. In the Transition Towns initiative, the Soil Association advises and certifies towns (and now cities) that achieve an appropriate 'green' designation. The coordinator of the Transition Town movement, Rob Hopkins, of Plymouth University, helped create the earliest 
Transition Towns in Kinsale, Ireland, Totnes, England, and Lampeter, Wales and advises the many others that have signed up.

Moving to theoretical analysis, the study of urban politics evolved towards a popular focus upon urban governance in the 1990s (Stoker 1999) it engaged with older regime theory (e.g. (Elkin 1986)) and particularly urban regime theory (Stone 1989; Stone 1993; Stoker \& Mossberger 1994). Urban regime theory was based on a critique of the pluralist theory of democracy of the early 1960s (Dahl 1961) and aligned with an élite theory approach associated with Dahl's erstwhile collaborator Charles Lindblom (Lindblom 1977). In this, it was argued that in market societies governments require economic growth to achieve political aims, a factor that places inordinate political power in the hands of business leaders. Regime theory accepts this and studies the manner in which the division of labour between business and governance actually functions, especially at the interface. Stone (Stone 1989) conceives of the regime as the medium in the relationship between politics and economy. Thus there is always, it is argued, some governance necessary for government to engage in actual governing. There have been a number of critiques of urban regime theory, the most serious of which is that it seldom addresses or examines the economic side of the equation. A second critique is that it excludes any room for political agency and variety in policy inputs and outcomes. Finally, due to its structural overdetermination it is unable to explain how the regime evolves or, normatively, how it might be changed (Ward 1996; Davies 2002).

Perhaps unsurprisingly, regime theory is nowadays commonly championed by leftwards leaning urban theorists, tending to inhabit a post-marxist 'regulation school' niche (Broomhill 2001). Nevertheless, and despite the critques discussed, the more subtle of these analysts have sought to overcome the economic determinism that urban regime theory introduced. A productive research group addressing UK urban sustainability governance of relevance to the present proposal adopts both the regulationist and urban regime theory mantles (Gibbs et al., 2000; Gibbs et al. 2002; While et al. 2004). Their position and findings are as follows. Arguing against a fundamentalist perspective that saw economic globalization facing urban governance with mounting pressure on protected open space, regulatory dumping, increased levels of consumption, negative environmental externalities, and increased material flows into and through the built environment, often at the expense of poorer residents and communities, they have sought to uncover evidence that environmentalism is not simply a matter of the demands placed on local state regulation by national government, business or pressures from upper and middleclass residents. Moreover, they suggest the apparent contradiction between a progrowth and a pro-green urban governance agenda may be illusory. Their focus is on the implications of environmental challenges for the composition and strategies of urban regimes. A sustainability perspective can provide a range of theoretical and empirical insights into urban enterpreneurialism, the changing context for urban politics and, to some extent, the social contradictions of urban environmental regulation under a regime of 'ecological modernization' (While et al. 2004).

While many of the empirical findings of this work are interesting, we do not propose an urban regime approach in this contribution, largely because the use of the regulationist-regime metaphor still over-narrows the research perspective to a classic and irremediable social conflict causality. Moreover, the 'urban coalition' model that regime theory tends to derive from economic governance analysis is clearly 
inappropriate in the context of a non-economic city governance analysis. Preferable is an approach in which, for example, innovative 'clean technology' interests or social movements including those of a 'counter-cultural' nature may be observed to have impacted upon raising 'green consciousness' such as green politics, 'green growth', organic farming and catering, green urbanism, and 'peak oil' analysts (Wolch 2007; Guthman 2004; Manning 2004; Kunstler 2005; Kahn 2006). To that end, as discussed in the introduction above a research approach drawing upon policy network interactions within city governance modes is preferred. This is proposed as a valid alternative conceptual model to regime theory by Mossberger \& Stoker (Mossberger \& Stoker 2001) citing Keith Basset's economic governance research on Bristol as an exemplar (Bassett 1996).

Policy networks are informal or semi-formal organisational mechanisms involving public and private individuals, groups, organisations and associations that interact around specific policies and programmes. Network stability derives from establishment of trust, reliability, reputation and customary rules to which network members adhere. Network maintenance is secured by the access members have to resources and influence in projects. Network management, brokerage and facilitation are necessary functions. Networks arise due to their low transaction costs, high learning efficiencies and associated knowledge gains in complex and multi-dimensional governance contexts ((Cooke \& Morgan 1998), 80). This chimes with Jensen \& Tollin (Jensen \& Tollin $2004)$ in their disclosure of how networks spread innovative policy knowledge in Copenhagen's sustainable development strategies and actions. For them, Dogma performs the role of 'environmental foreign policy' for its member municipalities. It acts as an umbrella for various environmental initiatives, rendering environmental policy more efficient. They also make a key point in referring here to the complexity issue where many networks being related to sustainable development evolve into a 'network of networks' structure, formalised into a 'project' with envisioned actions, rules, performance audits etc. as in the Dogma project, involving Copenhagen, Albertslund, Ballerup, Fredericia and Herning. This was successful and, for example, as network theory predicts, Dogma gave rise to new networks, like the 'Copenhagen Environmental Network' (since renamed Key2Green) involving the city and private entrepreneurs. Finally, a 'network governance' approach is a perspective with which this author is very familiar, albeit utilising it in a different context (Cooke 1995; Cooke 1996; Cooke 2002; Asheim \& Cooke 1998; Asheim \& Cooke 1999; Cooke et al. 2007).

\section{A conceptual framework}

The first step in preparing research upon 'green governance' and its opposite, involves mobilising secondary data on sustainability strategy, action planning and achievements for all cities of interest (above 100,000 inhabitants) in a given country, to clarify their status in terms of sustainability achievements and refine research instruments to be deployed in primary research. There should be three kinds of primary research instrument. The first of these is a survey communication delivered to one key respondent per each city (e.g. 66 chief environmental officers) inquiring, first, who else should be included on the project database covering the spectrum of politicians and other senior officers internal to the council significantly or mainly involved in city sustainability governance. These should be confined to those responsible and relevant (including purchasing and outsourcing officers) for the four 
municipally governed content areas that are main contributors to increased $\mathrm{CO}^{2}$ and other greenhouse gases. Within municipal jurisdiction these are, it will be recalled, food consumption, passenger transport, energy use and municipal waste. Second, this survey inquires about key external 'network governance' partners in the three other spheres identified in the introduction to this proposal: involving, associative governance (active climate-change lobbying by civic societies), knowledgeable governance (e.g. interfaces between city policy and specialist research or advocacy institutions), business context (local presence of, for example, 'cleantech' business; influential and demanding 'green' corporate citizens).

Having gathered the population of sustainability-relevant actors, a second and more elaborate survey should be administered to an average of ten of these respondents per city, assuming an approximate 4:6 internal/external split, i.e. a $100 \%$ sample of some 660 survey respondents. Where, as reported by Jensen \& Tollin (Jensen \& Tollin 2004), a city might have over 50 Local Agenda 21 neighbourhoods, the peak not grassroots networks would be sampled. A variety of electronic follow-up measures should be utilised to achieve a scientifically valid response rate. The logic behind surveying municipal respondents and relevant network members should begin by inquiring about implemented Agenda 21 planning and actions, followed by possible next steps such as cities commissioning or conducting 'ecological footprint' or any other type of emissions analysis (ecological life cycle analysis, for example), with follow-up actions and achievements, compliance with new advisory frameworks or regulations, and results of that, and so on. Questionnaires should be drawn to explore items broadly indicated below:

- Policymakers: Sustainability policy history; Policy development process; Policy learning, monitoring, reformulation; Benchmarking, networking locally and overseas; Policy representation, engagement with community; Cross-functional policy interaction; Multi-level policy interaction, co-ordination, disconnections; Marketing; Policy success; Uptake of policy instruments; Policy weaknesses, barriers, problems; Future policy ideas, visions, measures,

- Officers: Personal history regarding sustainability activity and interest; 'environmental footprint' or other emissions measures for city known; Perception of climate change as a policy issue at city level; Multi-level and lateral governance engagement or representation; Perceived significance of these; Policy learning and external network interaction; Joined-up internal and external governance initiatives focused on climate change issues,

- Transnational Networks: Initiatives taken to facilitate or animate sustainability forums, conferences etc. Attendance at external and overseas interaction events; Leadership roles in transnational sustainability networks; Perception of value of these; Organisation and involvement in foreign study visits to observe good practice; Learning gains or losses from engagement in transnational networks and visits; Attendance at relevant conferences, trade fairs and exhibitions for related to climate change, food quality, health, cleantech, recycling, waste management and energy sustainability home and abroad

- Civic Leaders: Values, norms, conventions; Leadership; Envisioning; Monitoring of action results; Learning processes; Benchmarking elsewhere, including overseas; Reputation, trust in communities; Business climate; Evaluation of status quo; Policy quality; Skills availability; Infrastructures; Weaknesses and barriers to progress; Future requirements and political, business or associative expectations 
- Knowledgeable Governance: Degree of satisfaction with city sustainability condition/benchmarking/emissions modelling; Engagement with city governance network 'platform'; advisory role on sustainable cities; research conducted for home-base and other cities on sustainability; Evaluations or assessments of 'ecological footprint'; Appropriateness of policies; Satisfaction with city receptivity to expressed climate change concerns; Transport emissions quality; Constructive criticisms; Benchmarking elsewhere, including overseas.

- Entrepreneurs \& Corporates: Entrepreneurial history; Skills profile; Locational rationale; Business performance; Markets (Domestic-Foreign; Customer status), E-business; Associations; Networks; Valuable interactions (Local, Regional, National, Global); Innovative/Creative visions, solutions; Infrastructure quality; Policy relevance; Policy adoption; Barriers to growth; Future expectations

Despite the theoretical preference for a policy networks over a regime approach to this research, there is interest, dimensionally, in two concepts that are noted in Mossberger \& Stoker (Mossberger \& Stoker 2001) arising from urban regime research, 'modes of governance' ((DiGaetano \& Klemanski 1999), 244-5) and 'symbolic regime' (Stone 1989) or preferably in this case 'symbolic governance' which is true to its original connotation in Stone (Stone 1989) of 'ideology or image' when cities are bent on changing these, for example, towards 'green governance.' Accordingly, the pre-research typology framework, to guide the research design and results analytically, differentiates cities that have both a high sustainability profile and action outcomes, from those with high profile but low action, and those scoring low on both (x-axis) (Fig. 1).

Finally, the third primary research module of the project would be a series of face to face interviews with an illustrative sample of the surveyed cities and their governance networks based on the Fig. 1 taxonomy outcome. Some forty-five interviews (five per city; 2:3 ratio internal:external to municipality) might be envisaged on the assumption that each taxonomy box in Fig. 1 will observe at least one entry. They should explore more deeply and with a semi-structured interview guide, matters of particular theoretical, analytical and policy interest to this research. Unexpected or inadequately articulated responses to survey questioning should be clarified. A considerable effort should be made to gain understanding for and the appropriateness of the allocation of cities to the nine categories. If reasons for modification arise, adjustments will be justified at this time. This part of the research may adopt the 'critical friend' interviewing approach pioneered by Charles Sabel (e.g. (Cooke 1995)), where observed performance is judiciously 'talked down' to elicit the full attention of the usually elite interview respondent. We also proposed to visit Copenhagen and Malmö for purposes of interviewing key personnel as a 'learning, monitoring and feedback exercise also involving sharing our results with them in discussions and presentations. These should involve, returning to Fig. 1, profiling where, on the yaxis cities are also entered in the post-research taxonomy according to their 'governance mode' contrasting well-networked and responsive to network interests, with weaker, responsive networking governance but proactive government, and a low networking propensity government category that reacts to governance and is accordingly exclusive regarding government. These alignments should thus, in principle, 
differentiate nine sustainability governance categories (Fig. 1) from which the UK interview sample is to be drawn. Variable weightings of content areas in relation to emissions contributions should be considered, and extent of network governance practice and quality of outcomes will be determinate in rankings.

\section{Conditions for climate change improvement in CEE}

In this section and in the space available we have time to consider two key variables that act as key conditions consistent with action to mitigate climate change problems in CEE cities, regions and national governments. The first of these is the extent to which the position regarding for example climate change causing global warming emissions are significantly worse than those of, for example, partner countries in the EU or future ones in OECD, for example, as cases in point. Another key variable is the quality of human capital in CEE countries that may be mobilised both to recognise any problematic characteristics scientifically and in to respond robustly to such a situation in policy terms.

Regarding the first issue, it may be clearly seen (Figs. 2 and 3) that energy efficiency is far worse in the three CEE blocs of EU, Balkans and Russian Federation than in EU (15) or OECD (Europe) or OECD (World).

Thus we see a marked difference in the levels of energy intensity utilised in the CEE countries compared to EU 15 and OECD countries. As can be seen from Fig. 4 (below), Denmark has the lowest energy intensity of all the 2003 European Union member states, some of those being Accession (i.e. former CEE) countries, which all show up with high energy intensity compared to the older EU member states. This is of course in line with our discussion in the Introduction of measures that have been taken even at city and local level in Denmark that contribute significantly to the reduction in energy use, wastage and

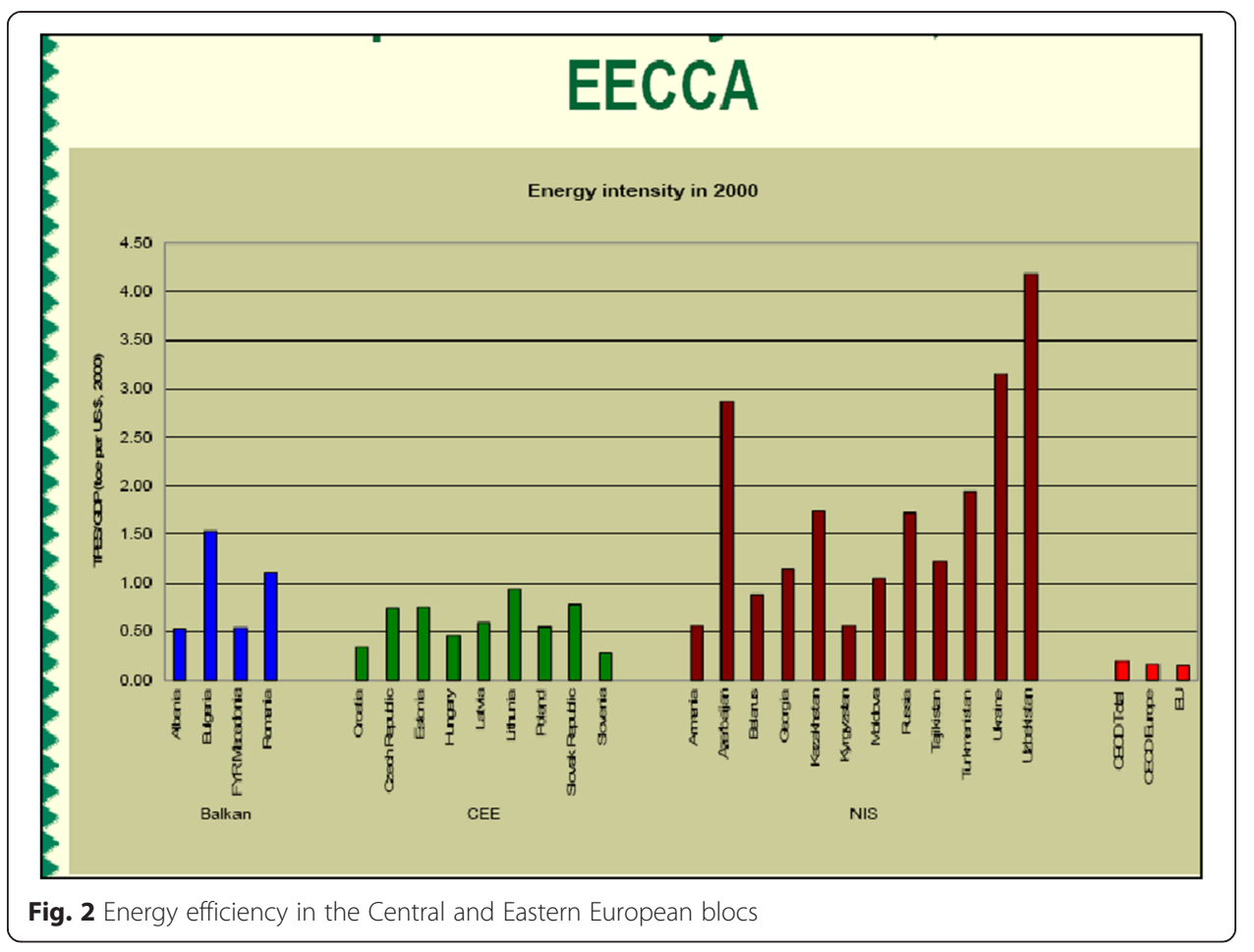




\section{Barriers to clean tech diffusion in CEE}

- Awareness level of socioeconomic benefits and lack of institutional capacities

- Strong lobbies of conventional (energy) industries

- Insufficient systems (e.g., grid) development and priority access for renewables to the grid in many countries

- Low level of investment subsidies and the availability of other economic and financial instruments

- Existing instruments and policies are not effective enough, e.g., feed-in tariffs are often too low or not guaranteed for long-term; pollution and wasting resources is not yet the more expensive option

- Lack of local technology innovation and the commercialisation of innovation

- Lack of local clean tech equipment manufacturing

Fig. 3 Causes of high energy intensity in CEE \& neighbouring blocs

other measures concerning the type of energy that Denmark utilises with a view to minimising its overall contribution to greenhouse gas emissions, notably $\mathrm{CO}^{2}$, $\mathrm{NOX}$ and Methane, the worst causes of global warming and consequent climate change.

Profile of country commitment to moderating climate change: Denmark

Denmark is a benchmark for the whole developed world in terms of its commitment to moderating its, albeit small, overall contribution to global warming. It is important to understand the role of democratic and informal (protest) politics in bringing about

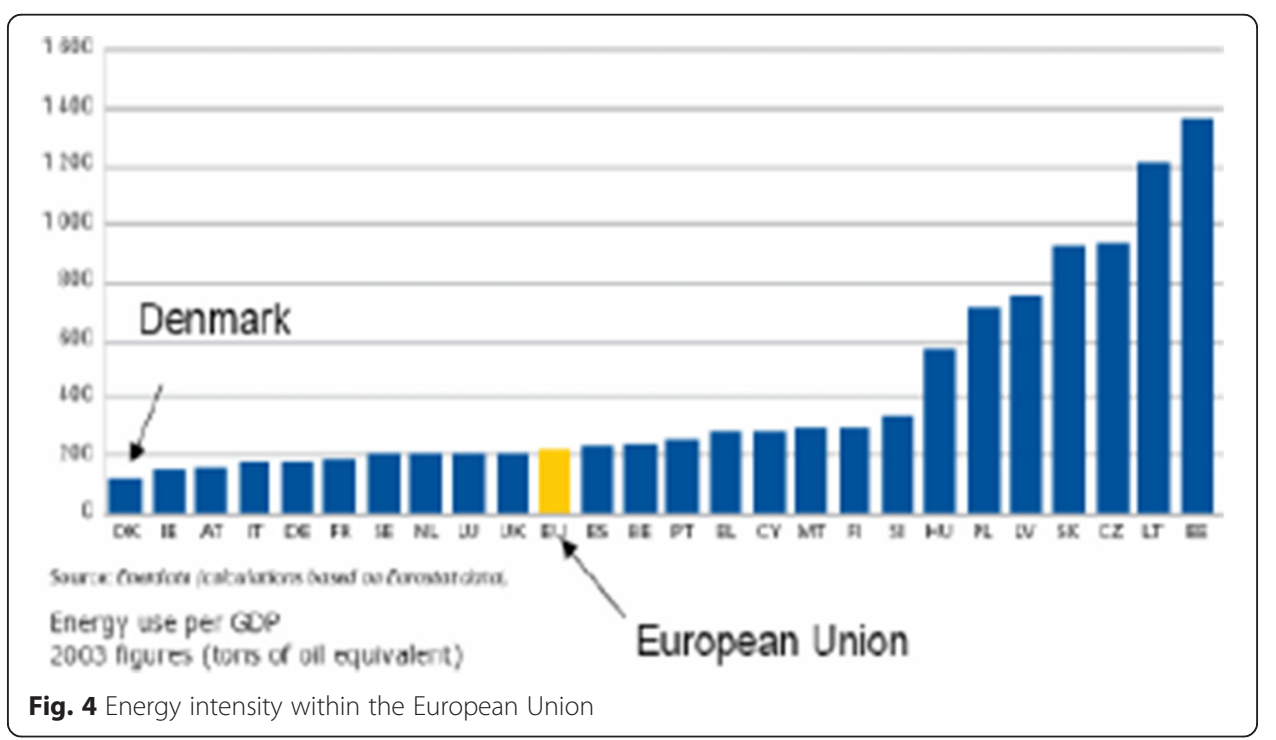


change over a relatively lengthy 30-year period. We can date Denmark's transition to clean energy, clean water and clean production methodologies from the early 1970s. This was when the first wave of serious popular concern about the environmental damage caused by economic growth occurring in Western countries. A series of social movements protested in the streets about the Danish government's nuclear energy plan. It was successful and caused the government to change to renewable energy strategy, including decommissioning its nuclear energy research institute Risø at Roskilde, near Copenhagen. This institute was charged with conducting research in other areas than nuclear energy, among which evolved renewable energy and issues relating to the 'greening' of Denmark. As will be indicated below, this led to the early development of clusters of renewable energy innovation, particularly around wind turbine and solar thermal equipment manufacture. By $200640 \%$ of Denmark's total energy needs were met by renewable energy, half of which derived from the by now enormous sea wind power farms that have been constructed offshore in Danish waters.

The impact of this is captured in data from the European Commission that shows Denmark as a whole being one of the Clean Technology leaders. Thus in 2007, according to the European Commission:

'....environmental technology is one of Denmark's largest business clusters, and includes 420 companies (60,000 employees)......analysis showed a number of 'strongholds' for potential to develop new environmental technologies clusters. They include offshore turbines and water purification.' (European Commission 2007)

The Danish Ministry of Economic and Business Affairs (FORA) report shows that a further 46 knowledge institutions consider themselves to be primarily active in environmental technology research. The FORA report shows one means by which the emergence of 'green innovation' clusters may be performed partly at the behest of government activity. This is referred to elsewhere as 'articulation of discourse' (Davenport \& Leitch 2008). This is a powerful cognitive and ideological process by means of which a discourse of action and promotion occurs within the state apparatus but articulated both to wider, global concerns, the interests and concerns of local business, and a modernising discourse expressing a policy-advisory consensus, in this case privileging clusters, innovation and climate change. For illustrative purposes, clearly, upon inspection, the quote from the European Commission (European Commission 2007) report is taken directly from the FORA report. This report shows how the FORA business and economic research unit defined environmental businesses and mapped a Danish cluster. This cluster occupies the abstract space of Denmark's national environmental industry. It is the loosest definition of 'clustering' as promulgated by Porter (Porter 1990). Hence apart from being in Denmark the 'cluster' has no geographical specificity of the kind Porter (Porter 1998) was rather more sensitive towards. He referred there to a cluster as:

'... a geographically proximate group of interconnected companies and associated institutions in a particular field, linked by commonalties and complementarities'

With regard to such clusters the most important analytical task is to establish the extent of interconnections, commonalities and complementarities since this is what 
distinguishes a localised cluster, its specialisation or differentiation and its potential for exploiting knowledge spillovers for competitive advantage.

In the FORA exercise, the first step was, as indicated, to identify the 'clump' of environmental technology firms throughout Denmark prior to articulating, somewhat assertively, that they constitute a cluster. Next, the 'cluster' is divided into sub-clusters based on the environmental challenge faced by the company or knowledge institution, i.e. into which sub-category of the abstracted cluster do specific actors 'fit'? Eight of these were identified. Next a pilot project was run examining three of these sub-clusters energy/climate change, water and chemicals. The rationale for selecting these first for further analysis was scale ('three sizeable clusters'), including high-tech smaller and large Danish companies, and areas in which Danish research institutes are perceived to be conducting world-class R\&D. The two target groups, firms and research institutes were then invited to profile their extent of 'green innovation', market expectations of their chosen course of action, and extent of collaboration (key to clustering) with others in this pursuit. Next, these answers were assessed in relation to sub-cluster critical mass (unspecified), knowledge (world class or not), and market potential (preferably global). Hence, to repeat, the articulated discourse of what have now become Denmark's environmental technology clusters draws on global excellence, innovativeness, collaboration and scale. Interestingly, photovoltaics, another pronounced cluster in north Jutland is not highlighted in this report (Cooke 2011).

Therefore on this basis five promising clusters were selected:

- Wind energy turbines (pioneered in Denmark since the 1970s, see below)

- Water purification (well-established businesses)

- Industrial biotechnology (well established, e.g. fermentation, enzymes)

- Biofuels (spin-offs from existing industry, for development)

- Fuel cells (spin-offs from existing industry, for development)

Companies in such industries were then asked what frame conditions (i.e. government support) would help them to evolve their potential or actual 'stronghold' status. These included regulation, stimulus to collaboration, public research funding and entrepreneurship. In the Appendix reporting contacts with research institutes only some $10 \%$ of these seem to have occurred outside Copenhagen, indicating the official 'cluster' discourse probably has a geography (and a 'scale' bias), which is centred upon the capital city even though substantial economic activity takes place in Jutland and elsewhere. This interpretation is supported in respect of the location of business interviewees, where larger Jutland firms like Vestas and Siemens Wind Power (wind turbines), Grundfos and Danfoss (both engineering) feature more strongly among the environmental technology interlocutors.

Nevertheless, focusing momentarily on wind energy, the question of whether what is in North Jutland is a wind-turbine cluster has to be addressed. On this, Andersen et al. (Andersen et al. 2006) point to the wind energy industry having passed through an early phase characterised by numerous small and medium-sized enterprises (SMEs) producing domestically-scaled wind power for individual farms and householders. But latterly, especially since the government subsidy to producers was removed in 2000, the scale of equipment has increased tenfold and sea power from large-scale offshore wind 
farms has come to predominate. As wind turbines have only some ten years life expectancy, most early wind turbines in rural Denmark will soon disappear if they have not already done so. So the current industry structure is large Danish (Vestas) or foreign (Siemens) producers and a supply platform of SMEs. There may be less local sourcing of key equipment like gearboxes than in the early days when North Jutland shipbuilding firms could adapt to meet the nascent wind energy demand. However, the scale and adaptability of German heavy engineering in cranes and related equipment means they now supply the Danish wind energy input market. Services and special logistics firms, the latter capable of transporting the now typically massive fibreglass turbine blades also exist in proximity as do a great many components suppliers.

\section{Biofuels from agro-food research in Wales}

Finally, as an indicator that relatively high and clean technology outcomes can arise from research in what is not normally considered a high technology industry, namely agriculture, we turn to recent developments that will have a major contribution to the moderation of global warming from high fossil fuel energy intensity by replacing it with agriculturally-derived Biofuel. Decades of research at the world-leading Institute of Grassland and Environmental Research (IGER) at Plas Gogerddan on the Cambrian Coast a few miles north of Aberystwyth have been devoted to the apparently prosaic aim of improving cattle and sheep fodder. After lengthy experimentation and some false moves in the knowledge exploration and exploitation processes, IGER in the 1980s came up with a global winner in fodder technology. This is a cross-bred rye grass product, the original variant of which was named AberDart. IGER patented this ryegrass because it is no ordinary grass. It is, indeed a supergrass, otherwise known as SugarGrass. It earns a royalty of $£ 100,000$ per year from seed merchants throughout the UK.

Whence SugarGrass? IGER bioscientists wanted to understand how to increase yield and quality of meat raised on Welsh grasses. This took them inside the rumen of these ruminants. It was discovered that enzymes that break down fodder inside the animals' stomachs consumed a substantial proportion of its energy value in the process. This deprived the animals of precious protein and explained why, although the meat might be sweeter from the clovers, thyme and other mountain herbs consumed, it remained lean not to say meagre. The innovative insight was to recognise the need for sugar-suffused cross-bred grass that would satisfy the enzymes yet leave plenty of extra protein for the beef and lamb to augment and improve the nutritional and flavourful protein in the meat. AberDart and its Aber-successors now take $50 \%$ of the UK ryegrass seed market, the products being marketed through Germinal Holdings.

Other brainwaves for the future will arise from research currently being conducted into the utilisation of yellow lupins as possible super-fodder, returning nitrogen to the soil as their seeds are turned into cake for cows and sheep, the rediscovery of kale as a general, improved cattle food, and a chemical fertilizer-free soil improvement regime based on utilisation of organic manuring, suitably modernised. These are all good news for the future of a low pollution agriculture with cleaner water, air and soil as important by-products.

But this is merely the beginning of the SugarGrass story. For, some eight years ago it was realised in tests that SugarGrass had twice the calorific value of sugar cane, the 
source of much of the world's biofuel. As the head of Bioenergy research put it, in interview, IGER had begun to evolve a second string to its grassland expertise by developing a renewables research division. One of the biofuel feedstocks in which it became supreme was the growing and processing of high calorific Miscanthus, more popularly known as Elephant Grass, an African tall grass that grows on marginal land. Accordingly it doesn't compete for land with food crops, one of the criticisms of the US and Europe's 'bolt for biofuels'. This has seen the ears and cobs of wheat and corn being turned into ethanol because it's there and subsidised, causing up to $40 \%$ increases in the price of such cereals, and grief in developing country food markets.

When asked who the competitors for IGER are in this specific bioenergy sub-field, IGER's biofuels head eventually came up with 'maybe Berkeley, now they have the BP endowment'. This refers to BP's $\$ 500$ million funding of a climate change research centre not, it seems, in the leading but the more glamorous grove of academe. He also mentioned the University of Illinois, but that was it - IGER has a current lead on both of them. But in any case, SugarGrass is also twice as calorific as Miscanthus and IGER favours this technology as the best long-term bet to replace oil.

So much so that the results of a key meeting with Welsh Government officials about the prospects of funds to help build an experimental biorefinery were said to be promising. Thinking had gone as far as to speculate that when oil ceases to be refined at the huge Milford Haven refineries in neighbouring Pembrokeshire, the pool of talent and infrastructural sunk costs would make them ideal candidates for becoming SugarGrass (and Miscanthus) biorefineries. These would continue to meet a huge share of the UK's future energy demand without greenhouse gases.

Hence economic development for an agricultural industry that has been hard-hit by food scares and a desperate need for farm-based diversification in rural Wales is also a consideration in this bioenergy research perspective. But it is not simply a spinout-venture capital model that is in mind. True to the traditions of cooperation among Welsh mountain farmers, there is a new vision of mixed farming whereby groups of farmers grow Miscanthus on their poorest soil, devote some fields for SugarGrass fuel cropping and raise quality Welsh Lamb or Welsh Black Beef on their best SugarGrass land.

Precision farming, whereby seed is automatically sown in varying intensities according to GPS field data on variability in soil humidity and fertility, held in the laptop in the farmer's tractor cab, makes for enhanced efficiency and effectiveness in this increasingly high-tech farming model. But the prospective is that farmer co-operation would enable them to undertake local, small-scale biorefining. SugarGrass is fermentable for extracting the juice that becomes ethanol to be used on farm or sold. But the dried remnants can also be used either as fodder or as feedstock for yet another bioenergy variant, biomass power station burning.

A bio-revolution seems to be afoot in rural Wales, as not only biofuels but biocomposites are also being researched and experimentally produced among groups of entrepreneurial farmers linked to Bangor University in north Wales. Mercedes cars use hemp-based insulation material of the kind being produced by an eight-farm group in Snowdonia and 'Future Farmers of Wales', a 140-strong association of younger farmers willing to diversify into biofuels, functional foods and cosmeceuticals (organic make-up) is thriving (Cooke 2011). 
Wales' energy intensity is actually quite high considering it is a largely rural member country of the UK as recent evidence shows (Table 1). This puts Wales near the top of the UK's GHG emissions index per capita, largely because of its history of coal production and steel manufacture in a few locations around the south and north Wales coasts. Thus the coal-burning Aberthaw, Deeside and Uskmouth power stations are major polluters despite efforts at implanting 'end of pipe' emissions controlling equipment, as are the oil refineries and cement works alongside the large Margam steelworks at Port Talbot. Clearly, over time and preferably quite rapidly this situation will have to be remedied in ways watched no doubt closely by the bigger polluting nations that are now committed to EU GHG reductions of 20 \% by 2020. Simultaneously, investment has been announced to take place for large scale non- $\mathrm{CO}^{2}$ emitting power generation facilities in various locations around Wales, burning bioethanol, wood pellets, exploiting tidal barrage power and wind energy. Hence, the expectation might be that renewable energy sources will come on stream in time to replace demand from what, it would further be hoped, would be a cleaner conventional energy industry that today, in Wales as in EU Accession countries and CEE blocs discussed above. By looking closely at what Denmark as a small sovereign country and Wales, a country within a larger sovereign state have done and will do, CEE countries can learn and implement their own strategies for helping save the planet from irreversible climate change caused by global warming contributed to by such greenhouse gases as those listed in Table 1.

\section{Conclusions}

We devoted this space to the subject of 'green governance' showing how some countries and municipalities have taken seriously their obligations under the Kyoto, Montreal Bali and in 2009 Copenhagen climate change protocols, while many others have not. It was shown what kind of activities can be successfully undertaken to moderate emissions in cities, notably Copenhagen in Denmark and Malmö in Sweden, both recognising that cities is where most citizens live and that much can be done to reduce emissions from energy consumption, through recycling and by 'clean' transport and environmental policies. It was subsequently shown how much GHG pollution is contributed to the earth's atmosphere by CEE compared to older EU member countries and argued that attention must swiftly be devoted by the governance systems at state and municipal levels in CEE to reduce these.

Table 1 Top greenhouse gas polluters in Wales

\begin{tabular}{ll}
\hline $\mathrm{CO}^{2}$ (million tonnes) & NO ${ }^{2}$ (tonnes) \\
\hline 1. RWE Npower, Aberthaw Power Station, 7.4 & 1. RWE, 28,325 \\
2. Tata-Corus Steel, Port Talbot, 6.8 & 2. Tata-Corus, 5,672 \\
3. E.On Deeside Power Station, 3.2 & 3. Chevron, 3,070 \\
4. Chevron Oil Refinery, Milford Haven, 2.3 & 4. Total, 2,238 \\
5. NPower Cogen, Barry, 1.7 & 5. Uskmouth, 2,009 \\
6. Total Oil Refinery, Milford Haven, 1.2 & 6. E.On, 1,410 \\
7. Baglan Operations, Neath, 1.2 & 7. Castle Cement, 964 \\
8. Uskmouth Power Station, Newport, 0.9 & 8. Blue Circle Cement, 801 \\
\hline
\end{tabular}

Source: Environment Agency Pollution Inventory Data 
It was further shown how understanding of and action to moderate the problem is being undertaken in the world's leading 'green economy' of Denmark but also in a part of the UK, namely Wales, that has some greater similarities to the heavy industry legacy of CEE. In Wales, a latecomer compared to Denmark, regarding emissions controls it was shown that even relatively humble crops like grass for cattle feed can, when improved through research and innovation, make a globally valuable source of bioethanol and biomass energy generation. It is incumbent on CEE countries to observe and apply these types of cellulosic sources of alternative, renewable energy as their fossil-fuel burning power stations inevitably decline unless they are appropriately modernised in line with new, exacting EU emissions targets. This can act as a lighthouse pointing the way for the CEE blocs that are not constrained by EU conventions but will nevertheless be made aware of their climatic obligations by the new, tougher constraints that will arise following the 2009 Copenhagen climate summit. The time for action has nearly passed, with some commentators saying we need immediate massive reductions in $\mathrm{CO}^{2}$ if global warming is to be steadied let alone reversed. A 'green' consciousness among the populace, comparable to the Danish protests that overturned government commitment to nuclear energy, is needed to achieve the result of truly 'green governance' in CEE as well as EU and OECD countries.

Competing interests

The author declares he has no competing interests.

Received: 8 May 2015 Accepted: 31 May 2015

Published online: 05 August 2015

\section{References}

Agency CEP. Working for the Environment. Copenhagen: Environmental Protection Agency; 2006.

Alliance CH. Cardiff Food \& Health Strategy. CHA: Cardiff; 2004.

Andersen P, Borup M, Olesen M. Innovation in energy technologies. Risø Energy Report. 2006;5:21-7.

Asheim B, Cooke P. Localised innovation networks in a global economy (1998) in. Comparative Social Research. 1998;17:199-240.

Asheim, B. \& Cooke, P. (1999) Local Learning \& Interactive Innovation Networks in a Global Economy (1999) in E, Malecki \& P. Oinas (eds.) Making Connections, Aldershot, Ashgate

Bassett K. Partnerships, business elites and urban politics: new forms of governance in an English city? Urban Stud. 1996;33:539-55.

Bastianoni S, Puselli S, Tiezzi F. The problem of assigning responsibility for greenhouse gas emissions. Ecol Econ. 2004;49:253-7.

Broomhill R. Neoliberal globalism and the local state: a regulation approach. Journal of Australian Political Economy. 2001;48:115-40.

City of Malmö Environment Department (2006) Environmental Programme for the City of Malmö, Malmö

Cooke P. Planet Europa: network approaches to regional innovation and technology management. Technology Management. 1995;2:18-30.

Cooke P. Policy networks, innovation networks \& regional policy. In: Heinelt H, Smith R, editors. Policy Networks \& European Structural Funds. Aldershot: Avebury; 1996.

Cooke P. Urban networks and the new economy: the impact of clusters on planning for growth. In: Begg I, editor. Urban Competitiveness. Bristol: Policy Press; 2002.

Cooke P. Growth Cultures: the Global Bioeconomy \& its Bioregions. London: Routledge; 2007.

Cooke P. Transition regions: regional-national eco-innovation systems and strategies. Prog Plann. 2011;76(3):105-46

Cooke P, Morgan K. The Associational Economy. Oxford: Oxford University Press; 1998.

Cooke P, De Laurentis C, Tödtling F, Trippl M. Regional Knowledge Economies: Markets. Cheltenham, Edward Elgar: Clusters \& Innovation; 2007

Dahl, R. Who Governs? New Haven: Yale University Press; 1961.

Davenport S, Leitch S. Creating space for the successor: the discourse strategies of pro- and anti-GM factions regarding the future of agriculture in New Zealand. New Zealand: European Planning Studies; 2008. p. 16.

Davies J. Urban regime theory: a normative-empirical critique. Journal of Urban Affairs. 2002;24:1-17.

DiGaetano A, Klemanski J. Power \& City Governance: Comparative Perspectives on Urban Development. Minneapolis: University of Minnesota Press; 1999.

Elkin S. Regulation and regime: a comparative analysis. Journal of Public Policy. 1986;6:49-72.

European Commission. 2006 Environmental Policy Review. European Commission: Luxembourg; 2007.

Freeman C, Littlewood S, Whitney D. Local government \& emerging models of participation in the Local Agenda 21 process. Journal of Environmental Planning \& Management. 1996;39:65-78. 
Gibbs D, Jonas A, While A. Changing governance structures and the environment: economy-environment relations at the local and regional scales. Journal of Environmental Policy \& Planning. 2002;4:123-39.

Gibbs D, Jonas AEG. Governance and regulation in local environmental policy: the utility of a regime approach Geoforum. 2000;31(3):299-313

Guthman J. Agrarian Dreams: the Paradox of Organic Farming in California. Berkeley: University of California Press; 2004. Jensen J, Tollin N. Networks as tools for sustainable urban development, presented at the 'Innovation. Munich: Sustainability \& Policy' international conference; 2004.

Kahn M. Green growth. In: Norman J, editor. Living for the City: a New Agenda for Green Cities. London: The Policy Exchange; 2006

Kunstler J. The Long Emergency: Surviving the Converging Catastrophes of the Twenty-First Century. New York: Grove; 2005.

Lever W. Charismatic urban leaders and economic development: good mayors and bad mayors in Europe. Space \& Polity. 2001;5:113-26.

Lindblom, C. Politics \& Markets. New York: Basic Books; 1977.

Manning R. Against the Grain: How Agriculture Hijacked Civilization. New York: North Point Press; 2004.

Mossberger K, Stoker G. The evolution of urban regime theory: the challenge of conceptualisation. Urban Aff Rev. 2001;36:810-35.

Porter M. The Competitive Advantage of Nations. New York: The Free Press; 1990.

Porter M. On Competition. Boston: Harvard Business School Press; 1998

Stern N. Stern Review on the Economics of Climate Change. London: Cabinet Office \& HM Treasury; 2007.

Stockholm Environment Institute. Reducing Wales' Ecological Footprint- Main Report. SEl: University of York; 2005.

Stoker G. The New Management of British Local Governance. London: Macmillan; 1999.

Stoker G, Mossberger K. Urban regime theory in comparative perspective. Environment and Planning C: Government and Policy. 1994;12:195-212.

Stone C. Regime Politics: Governing Atlanta. Lawrence: University Press of Kansas; 1989

Stone C. Urban regimes and the capacity to govern: a political economy approach. Journal of Urban Affairs. 1993;15:1-28.

Ward K. Rereading urban regime theory: a sympathetic critique. Geoforum. 1996;27:427-38.

While A, Jonas AEG, Gibbs D. The environment and the entrepreneurial city:searching for the urban 'sustainability; fix'in Manchester and Leeds. Int J Urban Reg Res. 2004;28(3):549-69.

Wolch J. Green urban worlds. Ann Assoc Am Geogr. 2007:97:373-84.

\section{Submit your manuscript to a SpringerOpen ${ }^{\circ}$ journal and benefit from:}

- Convenient online submission

- Rigorous peer review

- Immediate publication on acceptance

- Open access: articles freely available online

- High visibility within the field

- Retaining the copyright to your article 